\title{
Article
}

\section{Microcredit: Fulfilling or Belying the Universalist Morality of Globalizing}

\section{Markets?}

\section{Kenneth Anderson†}

This Article gives an account of the practice of microcredit that reveals its ambivalent relationship to global markets. Microcredit consists in nonprofit lending to poor communities, often at subsidized interest rates, to encourage small-scale entrepreneurial activity. Microcredit organizations view themselves, alternatively, as an extension of global markets into poor communities, designed to draw them permanently into the global economy, or as an efficient mechanism for providing aid to compensate the poor for their exclusion from the market. The Article argues that organizations would do well to clarify their relationship to the global market because that relationship has implications for how they should structure their lending program, whether they can become selfsustainable, and how they should measure their success. It further argues that, at a more general level, some residual ambivalence is unavoidable because the limits of globalization are unclear and microcredit necessarily is both an extension of, and a remedy for, the logic of the global market.

1. This Article began as the 1998 annual lecture of the Duke Law Journal, Nov. 9, 1998; it has been significantly reconceived in later years. My thanks to the Duke Law Journal for inviting me to speak.

t Professor of Law and Director, J.D.-M.B.A. Program, Washington College of Law, American Uniṿ.; Visiting Associate Professor of Law, Harvard Law School (2000); Board Chair and General Counsel, Media Development Loan Fund, Inc., a nonprofit venture fund promoting independent media worldwide through microcredit techniques; Special Counsel, Open Society Institute, New York; formerly General Counsel, Open Society Institute; former Director, Human Rights Watch Arms Division. All views expressed are strictly my own. Thanks to Lolita Lukose and Andrea Musalem for research assistance, and thanks to Jack Simon for handling child care duties for his grand-niece, Renee, while her father was researching and writing this Article. Email: kanders@wcl.american.edu. 


\section{INTRODUCTION: MICROCREDIT AND GLOBALIZING MARKETS}

This is an article about microcredit. ${ }^{2}$ Microcredit is a widespread, indeed celebrated, tool of contemporary international economic development work. Microcredit programs provide the poor with credit, capital, and training with which to establish their own small businesses, to become, in other words, small-scale capitalists - on the condition, however, of repaying the initial investment in their enterprises so that those funds can be recycled in new investments to poor people. Run by nongovernmental organizations (NGOs) or, in some cases, governmental aid agencies, in many places throughout the world, microcredit programs have emerged as an important mechanism on which the international development community has pinned its hopes for assisting millions of people out of poverty.

This is also, indirectly, an article about globalization and specifically about globalizing markets. Globalization is the process, we are told, that is remaking the world in our time, planet-wide in scope and aspiration, unstoppable, all-encompassing and yet diffuse in its effects, maddeningly difficult to conceptualize and yet omnipresent in the details of our daily consumption, production, travel, leisure, entertainment, education, and communication, and so impossible to ignore. It is a process about which many of the world's educated, broadly comfortable bourgeoisie, no matter where we live or work, ${ }^{3}$ feel profoundly ambivalent. This ambivalence today fills the pages of newspapers in their coverage of globalization, fills reporting on globalization by television and radio, fills intellectual and learned journals debating globalization's impact, fills the shelves of books published each year on the global markets. It is a constant source of debate and unease.

Microcredit, this Article suggests, is a global economic practice that seeks, on the one hand, to overcome this fundamental ambivalence about globalizing markets by making them available globally, universally, across the income ladder. On the other hand, according to this Article, the practice of microcredit reproduces an analogue of this ambivalence toward globalizing markets, particularly visible in microcredit's own highly ambivalent application of markets and market principles in international

2. A more generic and perhaps more descriptive term would be "microfinance," reflecting the fact that increasingly microcredit organizations engage in financing activities that extend well beyond traditional lending, sometimes including equity transactions. I will use microcredit and microfinance interchangeably to denote the broad range of government- or NGO-supported finance of all kinds provided to the poor.

3. At several points in this Article, I have specifically addressed myself to the world's bourgeoisie, in order to avoid the temptation ever present for those who work in international development matters of speaking not merely as, sometimes, advocates for the poor and, more often, ministers to them, but as though "we" were part of them. We are not. The "we" I have in mind in this Article, to whom this discussion is addressed, are the high bourgeoisie of the world, those with the wealth and time to worry both about the world's poor, the poor as such, and also about our own place in the world of wealth and its creation and distribution, including our sensibilities and our ambivalences about it. 
development work with the world's poor.

The fundamental ambivalence toward globalizing markets is stated easily enough in the abstract. On the one hand, we recognize and are attracted by the efficiencies of global markets. On the other hand, we fear the insecurity that we suspect genuinely global markets might producemarkets in which goods and capital flow globally but in which labor is relatively immobile and in which we desire labor to be relatively immobile in order to maintain social and cultural stability at home. And we fear also for others, the poor of the world. We fear for them that global markets might not prove a net benefit and, indeed, in the case of the world's very poorest, might simply leave them out altogether. While recognizing the benefits of globalizing markets, we also recognize, in one matter or another, one sector or another, with respect to one population or another, the possibility of market failure. Yes, of course, we have heard the panglossian arguments that all of us cannot help but benefit from global markets in the long term, but those arguments appear to us, frankly, a little too grounded in waiting for a long term that appears to be ever receding from the present, rather than in concrete experience, to be entirely reassuring. The possibility of market failure, in some matters or for some people, seems to us a distinctly live possibility. Hence we both want economic globalization and fear it.

What has microcredit to do with this? In the first place, microcredit works with the world's poor. If it also exhibits, as this Article suggests it does, a profound ambivalence about globalization-its mechanisms, processes, and outcomes - it does so in the context of the poor and not merely in the context of us, the world's bourgeoisie. More precisely, microcredit, because it is a development activity seeking to bring assistance from the haves to the have-nots, constitutes a point of intersection between the world's bourgeoisie and the world's poor. Microcredit therefore allows us to better understand the tensions generated by economic globalization, by providing a social space that is not limited by the experiences of the rich or of the poor but is instead shared between them.

Moreover, microcredit utilizes market mechanisms to achieve its development aims. As we shall explore in some detail, the distinguishing feature and fundamental appeal of microcredit is that it explicitly uses market incentives to create a credit market for the poor, a market characterized by two features: readily available funds and repayment requirements. We shall also have to consider in what ways and to what extent microcredit, through the extension of credit and the creation of enforcement disciplines for its repayment, has in fact embraced market mechanisms or has in fact elaborated other disciplinary mechanisms. At the outset, however, it can be said that microcredit's embrace of market mechanisms appears sufficient to show that microcredit shares with economic globalization a broad commitment to the principles of markets. This would suffice to make microcredit an important activity by which to understand the claims advanced on behalf of economic globalization, especially the claims made by many that markets advance the interests of 
everyone, including those of the world's poor. Yet that fact would not be enough to show that understanding microcredit contributes to an understanding of the ambivalence felt about the global market; if the intellectual framework of microcredit were nothing more than an endorsement of markets, no ambivalence would arise. An intellectual paradigm that simply endorses market logic generates no tension over global markets.

Microcredit is, however, more complicated than that. As an intellectual framework for international development, microcredit is deeply ambivalent as to whether microcredit represents the extension of markets, including global markets, to the world's very poor or rather an attempt to create faux markets for the poor, markets artificially created and maintained through subsidies, to remedy the global market's failure with respect to the poor and their needs. Both as an intellectual framework and as a concrete practice, through the many thousands of organizations and agencies worldwide that utilize its methodologies, microcredit exhibits deep ambivalence as to which of these possibilities most accurately depicts the relationship of economic globalization to the world's poor. It is an ambivalence, moreover, that is not merely conceptual but is also reflected in the culture of the international microcredit community-the loose groupings of nongovernmental organizations (NGOs) and governmental and international agencies that support microcredit. Parts of that community tend toward the view that microcredit is an extension of real markets downwards into the ranks of the poor; other parts tend toward the view that microcredit is the creation of alternative markets for those left out by the real markets; and still other parts move back and forth between these views according to case and circumstance. This ambivalence within the microcredit community and its practitioners has cognates in the ambivalence felt among the world's bourgeoisie toward the spread of the global market, and in particular toward the question of whether economic globalization in fact benefits and includes everyone.

At issue, however - what this Article hopes to illuminate through the examination of microcredit and its attitudes toward the market-is not economic globalization as such, but rather the morality of economic globalization and the morality of microcredit. That economic globalization has a morality, or at least that it is understood by some proponents as having a morality, might seem like a strange idea. After all, one of the constant themes of many of economic globalization's proponents, as we shall see, is that globalization is inevitable and that, therefore, the only relevant task is to accommodate ourselves to that fact. If that is the case, then discussion of the morality (whether a good morality or bad, defensible or indefensible) of economic globalization would seem rather beside the point. Yet the discussion surrounding globalization has been, on the contrary, filled with moralizing, and a large amount of it by proponents of economic globalization. It is not the case, as we shall see, that the debate over economic globalization is between proponents who shrug and say, "It is here, get.used to it," and opponents arguing from moral grounds. On 
the contrary, to judge by the literature on economic globalization, it is a matter of intense importance to many proponents of the global market that it be seen not merely to be the inevitable, unstoppable, coming train of the planet's economic future, but to be the world's economic system as a matter of the right and the good.

The needs of the world's poorest people have a particular place within the morality proclaimed with some frequency on behalf of economic globalization. It might have been the case that the needs of the world's poor would not be considered decisive in judging the moral worthiness of a global economic system. After all, the versions of utilitarianism that lend themselves most readily to the usual economic models of maximal satisfaction of wants do not necessarily contain special criteria addressing the needs of the worst off. Nor would it be obviously iniquitous to suggest that a planetary economic system, whether global capitalism or anything else, ought to be considered a success if it maximizes the satisfaction of wants among most people, even if it does not address the needs of the poor. Within national economies, for example, many major economic programs are undertaken that frankly have little if anything to do directly with the poor-changes in structures dealing with investments and financial markets, for example-and are considered great successes if they benefit the broad middle classes without having much to do with the poor except on some trickle down theory. We measure the merit of those and many other programs on the basis of what is good for most and not for the worst off. There is no obvious reason why the benefits of international trade and flows of capital ought not to be measured in the same way, by reference to most people rather than to the worst off.

That said, this is generally not how proponents of global capitalism, the global market, and economic globalization tend to make their case. On the contrary, as we shall see, many proponents of economic globalization tend to put the needs of the poor squarely at the center of their justifications. These proponents accept that it is an important test of the moral merit; they may see that test as being fulfilled in different ways, such as the view that growth in the world's economy as a whole will tend to help the poor by creating more opportunities for them, on a rising-tide-lifts-all-boats claim. There are many factual mechanisms claimed for how economic globalization will help the poor, but their striking feature is less that they are correct or incorrect in any particular case than that such claims are regarded as central to the case for economic globalization in the first place. It is particularly striking in the case of political conservatives arguing for the global market, because in adopting such criteria, they begin at least to approach something of the liberal egalitarianism of John Rawls' famous difference principle, under which (very roughly) the sole moral test of an economic policy is whether it improves the situation of the worst off. ${ }^{4}$ In at least some cases, they would appear to accept with respect to the global economy a criterion of morality that they might well reject as excessively

4. JOHN RAWLS, A THEORY OF JUSTICE (rev. 1999). 
egalitarian if applied, for example, to the national economy of the United States. I will say for myself, at the outset, that this more stringently egalitarian test seems to me morally the right one. ${ }^{5}$ More relevant, however, to the purposes of this Article, the fate of the poor is a moral criterion that has been widely accepted by those seeking to proclaim global capitalism as not merely the fate of our world but a just result as well. ${ }^{6}$

The hope for this Article, therefore, is that it will illuminate aspects of the morality of microcredit as well as of globalizing markets generally. The focus is on microcredit, its structures, practices, economic logic, and moral sensibility, but it is my hope that at least some of these features will be felt to resonate with features of economic globalization. The Article proceeds by discussing microcredit and its practices, and in particular the way in which microcredit draws upon market principles as its organizing logic. The Article then turns to consider the relationship of the world's poor and very poor with the emerging global market system and the morality that underlies the advocacy of global markets, for whom real gains for the poor is an important test of the global system's legitimacy. Microcredit is then reconsidered as a practice which might be regarded, on the one hand, as an exemplary tool of mediating the relationship between the poor and global markets or, on other hand, as a tool for relieving the impact of global markets on the poor and relieving market failure with respect to the poor or both simultaneously. The Article concludes deliberately on its own note of ambivalence, because my view is finally that both microcredit and globalizing markets carry these benefits and burdens togetherirremediably together.

\section{MICROCREDIT AND MARKETS}

\section{A. What is Microcredit?}

The core activity of microcredit is not difficult to explain. Microcredit

5. Some would make the requirement of egalitarianism much more stringent. Central to the moral argument for the rapid universal expansion of the unregulated market-place is the claim that, as a result, living standards will rise faster and incomes along with prices, interest rates and cost of doing business will converge. The promise of higher and converging incomes is necessary to justify the pain of dislocation that inevitably accompanies fast-paced creative destruction.

Jeff Faux \& Larry Mishel, Inequality and the Global Economy, in GLOBAL CAPITALISM 93 (Will Hutton \& Anthony C. Giddens eds., 2000) (emphasis added). This form of egalitarianism requires a convergence of incomes, not simply that the incomes of the poor increase, whether or not, or how fast, the incomes of the better off increase. This Article, however, adopts only a less stringent egalitarianism, one requiring only a Rawlsian improvement in the situation of the worst off, believing it a more accurate portrayal of what proponents of global capitalism actually assert.

6. The editorial page of the Wall Street Journal, for example, proudly announced that the "global trend is toward market-driven prosperity and individual empowermerit." Editorial, So 19 th Century, WALl ST. J., Oct. 25, 2000, at A22. 
consists in lending funds to the poor in order that they use them to start small businesses. The loans are then collected, typically with some rate of interest, so that they can be relent to other borrowers (or else turned over to the original borrower for purchase of more supplies, gradually expanding the business). ${ }^{7}$ The poor typically might use the funds to purchase supplies or equipment. These supplies may be food staples for making tortillas or other food for sale on the street, while equipment may be a sewing machine to be used in textile manufacture..$^{8}$ Some of the more unusual microcredit businesses include the village cell phone business pioneered by the famous microcredit bank in Bangladesh, the Grameen Bank; in villages without telephone landlines, cell phones have the potential to be a convenient and profitable village business. ${ }^{9}$ In rural areas, businesses will often be in agriculture, such as purchasing new breeding animals, and in urban areas, the business may be street food sales, house painting, bicycle repair, or many other things. ${ }^{10}$ With thousands of microcredit organizations operating worldwide, in activities that encompass these ordinary lending operations and, increasingly, more sophisticated lending activities to larger businesses, and which must accommodate diverse cultural and social customs of local societies, the rule is heterogeneity. ${ }^{11}$

That same heterogeneity applies as well to the reasons why microcredit is used by the development and aid community, as journalist Peter

7. "Microfinance has evolved as an economic development approach intended to benefit low-income women and men. The term refers to the provision of financial services to lowincome clients, including the self-employed." JOANNA LEDGERWOOD, MICROFINANCE HANDBOOK: AN INSTITUTIONAL AND FINANCIAL PERSPECTIVE 1(World Bank ed., 1999).

There is often disagreement about what precisely constitutes microfinance. Different schools of thought exist as to how small loans have to be to qualify as micro and the purpose to which they should be used. . . . [M]icrofinance embraces lending to individuals and groups hitherto outside the reach of the conventional banking system with the broad aim of promoting small business employment.

PETER MONTAGNON, CTR. FOR THE STUDY OF FINANCLAL INNOVATION, CREDIT WHERE CREDIT IS DUE: BRINGING MICROFINANCE INTO THE MAINSTREAM 8 n.ii (1998).

8. See, e.g., MUHAMMAD YUNUS, BANKER TO THE POOR: THE AUTOBIOGRAPHY OF MUHAMMAD YUNUS, FOUNDER OF THE GRAMEEN BANK 64-72 (1998) (describing microlending assistance to Bangladeshi farmers following the famine of 1974). Obviously, given the thousands of microcredit programs in existence across the world and the millions of microcredit borrowers worldwide, one could fill a book with anecdotes of the variety of activities funded by microcredit; they are as varied as the economic life of the poor around the world. Rather than multiply anecdotes, this Article seeks to concentrate on certain analytic features thought relevant to understanding microcredit at a level above the purely anecdotal.

9. See ThOMAS Friedman, THE LeXUS AND THE OlJVE TREE 361-62 (2d ed. 2000). My own work as an attorney for the Open Society Institute, which has provided funding for this cell phone initiative, confirms Friedman's account.

10. See generally ALEX COUNTS, GIVE US CREDIT (1996) (giving an account of the rise of microlending, including extensive case studies).

11. A Nov., 2001 Wall Street Journal article estimated that there were some "7,000 so-called microlenders with 25 million poor clients worldwide." Daniel Pearl \& Michael M. Phillips, Small Change: Bank That Pioneered Loans for the Poor Hits Repayment Snag: 'Microcredit' Icon Grameen Faces Questions as Rate of Delinquencies Rises: Mrs. Begum's Missing Cow, WALL ST. J., Nov. 27, 2001, at A1. 
Montagnon has put it, "missionary zeal."12 One fundamental reason, however, harking back to the origins of microcredit programs in the 1970s, is the widespread perception that traditional development programs, funded by international agencies such as the World Bank but run through developing country governments and consisting frequently of large-scale, capital-intensive infrastructure projects such as dams and power plants, have largely failed to reach the world's poorest or to improve their life chances. $^{13}$ In some cases such large-scale projects have helped poor societies, in some cases they have badly hurt or wiped out poor communities, and in many cases they have left the lives of the very poorest people untouched. ${ }^{14}$ Microcredit, in other words, in part developed not out of any great love for the ideology of the market, but instead out of a desire to find an alternative mechanism for putting funds directly into the hands of the poor in ways that would make an immediate difference to their economic prospects. When Muhammad Yunus, for example, founder of the Grameen Bank in Bangladesh, first decided to loan a village woman a few dollars to purchase thread for textile work so that she would not have to go to the moneylenders, his motivation was to allow her to avoid the existing credit market, such as it was, rather than some doctrinal belief in the virtue of markets. ${ }^{15}$

A second fundamental reason for microcredit gaining such extraordinary ground lies in the growth in political power of international NGOs. ${ }^{16}$ During the past decade, international NGOs have occupied a certain moral high ground in demanding accountability from public international agencies such as the World Bank, claiming that NGOs are better positioned than international agencies both to assess the impact of programs on the poor and, in many cases, to deliver aid programs. At the same time, many international and prominent state aid agencies have moved to see NGOs as their most important subcontractors in the delivery

12. MONTAGNON, supra note 7 , at 5 .

13. As Ledgerwood writes,

Microfinance arose in the 1980s as a response to doubts and research findings about state delivery of subsidized credit to poor farmers.... Beginning in the mid-1980s, the subsidized, targeted credit model supported by many donors was the object of steady criticism, because most programs accumulated large loan losses and required frequent recapitalization to continue operating. It became more and more evident that market-based solutions were required.... Since the $1980 \mathrm{~s}$ the field of microfinance has grown substantially.

LEDGERWOOD, supra note 7 , at 2.

14. For an example of the extensive literature critical of the Bretton Woods financial institutions (including the World Bank), see 50 YEARS Is ENOUGH: THE CASE AGAINST THE WORLD BANK AND THE INTERNATIONAL MONETARY FUND (Kevin Danaher ed., 1994).

15. YUNUS, supra note 8 , at 5-8 (giving an account of his first experience lending to Bangladeshi village women).

16. On the rise of the international NGO movement and its importance in international relations today, see, e.g., Kenneth Anderson, The Limits of Pragmatism in American Foreign Policy: Unsolicited Advice to the Bush Administration on Relations With International Nongovernmental Organizations, 2 CHI. J. INT'L L. 371 (2001) (outlining the reasons for the influence of NGOs in international affairs). 
of aid to poor-bypassing governments that are seen as inefficient and corrupt. The intertwining of NGOs and international aid agencies has gone a long way; as the Economist has noted, for example, with respect to NGOs and the World Bank:

[T] he NGOs are surprisingly quiet about the World Bank. The reason is that the Bank has made a huge effort to co-opt them. James Wolfensohn, the Bank's boss, has made "dialogue" with NGOs a central component of the institution's work... in the Bank's field offices. More than half of World Bank projects last year involved NGOs. Mr. Wolfensohn has built alliances with everyone, from religious groups to environmentalists.... From environmental policy to debt relief, NGOs are at the centre of World Bank policy. Often they determine it. ${ }^{17}$

Following the 1999 Seattle protests that scuttled meetings of the World Trade Organization, criticism has started to mount of the influence of the NGOs and, indeed, of their own accountability (i.e., lack thereof), ${ }^{18}$ but NGO endorsement of microcredit-more precisely, NGO efforts first to undertake microcredit and then to bring it to the attention to such agencies as the World Bank-has been of immense importance in the rise of microcredit and its great prestige. ${ }^{19}$

A third fundamental reason for the rise of microcredit-closely related to the second - lies in the gradual gendering of international development theory and practice. ${ }^{20}$ It is now widely accepted that reaching the world's poorest people means reaching women and, by extension, the families for which they so often bear overwhelming burdens. ${ }^{21}$ In some instances,

17. Special Report: Citizens' Groups, THE ECONOMST, Dec. 11, 1999.

18. See, e.g., Justin Marozzi, Whose World Is It, Anyway?, THE SPECTATOR, Aug. 5, 2000, at 14-15 (quoting Fareed Zakaria, managing editor of Foreign Affairs, who voiced concern that "governments will listen too much to the loud minority [NGOs] and neglect the fears of the silent majority.").

19. See YUNUS, supra note 8, at 13-26 (describing the struggle in getting the World Bank to accept the microcredit paradigm).

20. See, e.g., MARTHA Nussbaum, WOMEn and HUMAN DEvelopment: THE CAPABILITIES APPROACH (2000) (arguing that, as a matter of fundamental justice, women in developing countries must have equal access to the resources necessary for living a full, autonomous life).

21. See Microcredit Summit, DeClaration AND Plan OF ACTION 4 (Feb. 2-4, 1997) [hereinafter MICROCREDIT SUMMTT DECLARATION]:

In both developing and industrialized countries, poverty has a predominately female face. The United Nations Development Fund for Women (UNIFEM) finds that women earn only 10 percent of the world's income, and own less than 10 percent of the world's property. Of the more than one billion adults who have no access to basic education, more than 60 percent are women. Of the 1.3 billion absolute poor todaypeople living on less than US\$1 a day-over 900 million are women. Further, the poverty of women generally results in higher birth rates, and the physical and social underdevelopment of their children.

See also CHERYL ReNe RODRIGUEz, WOMEN, MicRoENTERPRISE, AND THE POLTTICS OF SELFHELP (1995), at 15-47 (providing a survey of women's entrepreneurship). 
microcredit programs are aimed specifically at women as part of an effort to reach the world's poorest (who are disproportionately women). ${ }^{22}$ Shut out from traditional sources of credit that might (or might not) be available to men, microcredit aimed at women in particular is widely regarded as an important instrument in the relief of poverty. ${ }^{23}$ In other instances, microcredit programs for women appear to be aimed at the empowerment of women and their economic independence from male-dominated economies among the poor for their own sake, as a tool for raising consciousness and not merely as a tool for relieving poverty overall. ${ }^{24}$ In either version, it is nearly impossible to overestimate the importance of the international women's movement in setting agendas for microcredit aimed at poor women worldwide and in giving the issue a front seat in policy discussions of development issues. At the same time, it should be noted that a feminist critique of microcredit is also gradually gaining ground, among other reasons on the view that the mechanisms of microcredit that prompt borrowers to repay are often highly coercive as well as on the view that microcredit has sometimes been touted as a substitute for, rather than an adjunct to, fundamental investments in women's education and health. ${ }^{25}$

22. See e.8., YUNUS, supra note 9, at 93-98. There has also been criticism of what some see as an excessive focus on women as the object of anti-poverty efforts.

"[T]here's another issue of whether your clients are legitimate if they're not women. That was another sort of - what can I say? - concept that was promulgated, and not only by the Microcredit Summit. That women are the most disadvantaged, and the most creditworthy. ... I can't say that I have seen any difference between men and women in the relative need for microfinance support, no difference in the rate at which they apply to us for money, nor in the degree to which their applications are accepted, nor in the degree to which they pay back their loans on time. There is no statistically significant difference between the sexes on those things [in Poland] at all. And I can't believe that Poland is the only country in the world where that is true."

MICROFINANCE: CONVERSATIONS WITH THE EXPERTS 40 (Charles Oberdorf ed., 1999) [hereinafter CONVERSATIONS] (remarks by Rosalind Coprisarow).

23. See MICROCREDIT SUMMIT DECLARATION, supra note 21, at v (emphasis added): The Microcredit Summit is but one part of a much larger effort to end poverty. To be successful, the overall movement to end poverty will require the implementation of a broad range of strategies. Building institutions capable of providing microfinance services, specifically credit for self-employment and savings capabilities, to 100 million of the world's poorest families, especially the women of these families, is just one of these strategies.

24. Ledgerwood draws this distinction when she urges that a microcredit organization needs to know its own goals - including whether its goals are, for example, to relieve poverty, to encourage economic growth, "[o]r to help poor women develop confidence and become empowered within their families." LEDGERWOOD, supra note 7, at 4 (emphasis added).

25. Lucie E. White, Feminist Microenterprise: Vindicating the Rights of Women in the New Global Order?, 50 ME. L. REV. 327, 332 (1998). 


\section{B. Why Microcredit? Does it Seek to Alter a Rational or Irrational Refusal of Commercial Markets to Lend to the Poor?}

Despite the heterogeneity of microcredit activities as well as the heterogeneity of reasons underlying the rise of microcredit as a development strategy, the economics of lending imposes some common conditions upon microcredit practice. ${ }^{26}$ Thus one important question common to all microcredit activities is why credit is needed from microcredit organizations at all. After all, they are outsiders to the local communities of the poor - typically government providers of credit to the poor, international agencies, or NGOs operating either with donated funds or funds received from governments or international agencies. ${ }^{27}$ Are there no internal funds, is there no capital market at the village level? ${ }^{28}$ In many other development situations, after all, the influx of outside funds can distort local markets in damaging and sometimes dangerous ways. The influx of food aid in a famine situation, for example, if not managed carefully, can result in a collapse of prices for locally produced grain that puts local producers out of business and results in permanent dependency on foreign charitable supplies or at least severe temporary disruption of local agriculture. Does microcredit not run the risk of distorting local capital and credit markets in similarly damaging, and often unanticipated, ways? ${ }^{29}$

One typical answer is that such credit and capital as are available to the very poor are available only from traditional moneylenders who lend at loan-shark rates that make regular commercial dealings impossible. ${ }^{30}$ Traditional moneylending is sometimes about investment and can play an important role in informal finance, but often it is about distress; money is loaned for medicine and for food in urgent situations where the choices are often death or lasting injury. Interest rates can be fantastically high, of

26. A useful handbook for consideration of these common economic and institutional factors is THE NEW WORLD OF MICROENTERPRISE FINANCE: BUILDING HEALTHY FINANCIAL INSTITUTIONS FOR THE POOR (Maria Otero \& Elisabeth Rhyne eds., 1994) [hereinafter NEW WORLD]; see also the series of handbooks, occasional papers, and documents available from ACCION International at its website http://www.accion.org.

27. See MONTAGNON, supra note 7 , at 19 for a helpful table showing the breakdown of sources of funds used in microcredit, using World Bank data.

28. See LEDGERWOOD, supra note 7 , at 2 (noting that " $[\mathrm{m}]$ oneylenders, pawnbrokers, and rotating savings and credit associations are informal microfinance providers and important sources of financial intermediation" to the poor).

29. Prior to the establishment of market-based microcredit programs, "[d]irected credit and controlled interest rates [led] to distortions and waste in the allocation of precious development resources." CARLOS CASTELLO ET AL., EXPOSING INTEREST RATES: THEIR TRUE SIGNIFICANCE FOR MICROENTREPRENEURS AND CREDIT PROGRAMS 7 (ACCION International Discussion Paper Series No. 6, 1991).

30. For a generally more sympathetic treatment of traditional moneylenders, see ROBERT PECK CHRISTEN, WHAT MICROENTERPRISE CREDIT PROGRAMS CAN LEARN FROM THE MONEYLENDERS 11 (1989) (ACCION International Discussion Papers Series No. 4) ("[T]here are proven methods of operation by moneylenders which, from a financial perspective, should be emulated by microcredit programs"). 
course, where the opportunity cost, so to speak, is death. ${ }^{31}$ But distress lending is not commercial capital, and it is that gap that microcredit funds seek to bridge. ${ }^{32}$

A second question common to all microcredit-and one which a microcredit organization, like any banker, ignores at its peril-is how to balance risk and return in microlending activities. How, that is, to ensure that risks are properly priced across the microcredit organization's lending portfolio so that the microcredit organization does not soon find itself out of business on account of expenses and defaults exceeding repayments and interest received on loans? ${ }^{33}$ This seemingly mundane question of risk and return raises in its turn profound questions about how the purpose and function of microcredit within a poor community ought to be conceived. Ought the purpose of microcredit, offered by an outside agency typically using subsidized capital, be to overcome a rational refusal by commercial lenders to lend or an irrational refusal, or both? The answer to this question in any particular circumstance will go a long way in identifying the risks that the microcredit organization faces. The answer also will go a long way in clarifying the relationship between microcredit as a development strategy and markets, because it will explain the microcredit organization's rationale for what it might regard as creating a credit market where none existed but what might equally be seen as distorting the existing local credit market.

Credit from microcredit providers might be needed in poor communities because commercial providers of credit rationally refuse to lend to the poor, because in fact the poor present greater risks of default than wealthier and typically bigger borrowers. ${ }^{34}$ They often do not have

31. Moneylenders can charge interest rates of 365 percent a year even without compounding. MONTAGNON, supra note 7 , at 8.

32. As both Christen and Montagnon note, however, moneylenders sometimes do play the role of genuinely commercial providers of credit even when lending money at such high interest rates. As Montagnon notes with respect to the Tamilian moneylenders in Cochin, they

are not vilified by their customers. Indeed, borrowers appear grateful for an opportunity to receive credit. For those that use the credit to build a business, a high level of interest is eminently affordable. This is because micro-enterprises are usually labour-intensive, with few fixed assets. Credit is usually applied to the purchase of simple tools, which can make a huge difference to productivity, or to working capital, which is passed through the business with enormous speed. A hawker in Jakarta, for example, may borrow Rs 10,000 to buy fruit and vegetables from a wholesaler which he will sell on the street for Rs 20,000. The moneylender may charge interest at Rs 100 a day-equivalent to 365 percent a year even without compounding. Yet the hawker can afford the interest because his-or (as is often the case) her-return is generated so quickly that the high cost of capital eats up so little profit.

MONTAGNON, supra note 7 , at 8.

33. See LEDGERWOOD, supra note 7, at 149 (discussing one method of setting interest rates).

34. This is a proposition sometimes denied by the microcredit movement. The Microcredit Summit Declaration, for example, says flatly that microcredit programs "representing different models and operating in different cultures have discovered that very poor people achieve strong repayment records. In developing countries, late payment and 
collateral in the form of real or other tangible property to pledge for the loan; effectively, they have only their labor to offer as collateral..$^{35}$ If that is the case, then the function of microcredit is to subsidize and jump-start local microenterprises to get them going, whereupon, with a pumppriming infusion of credit, they will become profitable businesses able to borrow and repay microcredit loans.

Yet classic efficient market theory would warn us to ask what special facts microcredit providers (themselves often foreign to the local culture) know about microbusinesses of the poor that local commercial credit providers do not know, such that there is reason to believe that with initially subsidized credit these businesses will work out over the long term. If lending to microbusinesses could have been developed as a profitable niche lending business, would it not have developed already without the need of outside microcredit providers? And if the answer is that the credit is needed because these microbusinesses need subsidy over the long run, then that may be a welfare rationale for offering credit, but it is a radically different one than offering it as pump-priming alone. The rationale for microcredit would have to be that the welfare subsidy offered is more efficiently used to subsidize the business rather than simply directly granting the same aid purposes of direct consumption because, even if the microbusiness cannot fully cover its costs, ${ }^{36}$ it can generate profits that create a net utility greater than a direct consumption subsidy alone would. (These net utilities might, and typically do, include intangible utilities in the form of greater training and expertise and ability to engage in other forms of economic activity; they may include such things as learning how to manage money or rudimentary bookkeeping or other skills. $)^{37}$

bad loan ratios are comparable to or below those of conventional banking houses." MICROCREDT SUMMIT DECLARATION, supra note 21, at 10. However, as this Article suggests further on, in keeping with the observations of others, measuring default rates alone is not sufficient; higher monitoring and transaction costs associated with microcredit that prevent delinquencies from developing must also be taken into account as measures of risk posed by loans to poor borrowers. See supra this section. See generally KATHERINE STEARNS, THE HIDDEN BEAST: DELINQUENCY IN MICROENTERPRISE CREDIT PROGRAMS 7 (1991) (ACCION International Discussion Paper Series No. 5) ("Despite the importance of delinquency to the health and viability of credit programs, many program managers are unaware of their true portfolio quality, and ignorant of the impact that delinquency has on their financial situation.").

35. For a discussion of loan collateral in microcredit and alternative forms of collateral, see LEDGERWOOD, supra note 7, at 137-38.

36. See infra Section II.C for a discussion of the financial self-sustainability of microfinance institutions.

37. Increasingly microcredit sees itself as a movement operating according to this welfare efficiency rationale. As Ledgerwood puts it,

[i]n addition to financial intermediation, many [microfinance institutions] provide social intermediation services such as group formation, development of self-confidence, and training in financial literacy and management capabilities among members of a group. Thus the definition of microfinance often includes both financial intermediation and social intermediation. Microfinance is not simply banking, it is a development tool.

LEDGERWOOD, supra note 7 , at 1. 
Alternatively, however, microcredit might be needed because local commercial markets act irrationally insofar as they refuse to lend to the poor. Local lenders might, for example, act irrationally insofar as they refuse to accept anything as collateral for loans other than tangible assets. Microcredit advocates often argue that lending to the poor is not as risky as traditional, tangible collateral-based models might suggest, and they point to apparently high rates of repayment as evidence that commercial markets irrationally deny credit to the poor on a misguided view of collateral. More recent research has called into question whether repayment rates are in fact as high as sometimes claimed and, by implication, whether the refusal to lend without traditional collateral is irrational. ${ }^{38}$ Still the point is well taken that, as in the case of the lending based around real property at various points in the financial history of such diverse places as the United States, Japan, and the countries of southeast Asia, real estate can turn out to be cold comfort in the event of default. ${ }^{39}$ However, in addition to repayment rates not being as uniformly high as sometimes suggested, the riskiness of uncollateralized loans to the poor may well express itself in the form of the high monitoring and transaction costs that microcredit programs incur in order to achieve repayment. The cost of risk, that is, is front-loaded in the form of monitoring costs.

Another form of market irrationality on the part of local commercial lenders is their refusal in many places to lend to women. In some cases, this might be simply a custom. In other cases, it might be a response to an embedded legal system that, for example, makes it difficult for women to sign for loans without the co-signature of a male relative or other legal mechanisms that give women, or in some case married women, less than full legal status in commercial transactions. It might be the legal or customary ability of a male family member to force money borrowed by a woman member of the household to be handed over to him. In some cases one might describe the system as a whole as irrational, while recognizing as rational the individual lender's conformity with that system. In such

38. According to Deborah Drake and Maria Otero, for example, experience shows that "the poor are responsible borrowers and savers. Efficiently run programs have maintained extremely low late payment and default rates." DEBORAH DRAKE \& MARIA OTERO, ALCHEMISTS FOR THE POOR: NGOS AS FINANCIAL INSTITUTIONS 104 (1992) (ACCION International Monograph Series, No. 6). For a frank and skeptical discussion, however, of whether repayment rates are in fact so rosy, see CONVERSATIONS, supra note 22, at 15-17. Even the fabled Grameen Bank, with its much touted 95 percent repayment rate, appears to have pronounced difficulties with delinquencies at a rate far higher than ordinarily acknowledged by the bank and its many defenders. See Pearl \& Phillips, supra note 11, at A1 (stating that its "iconic status owes a lot to an almost miraculous loan repayment rate of 'over $95 \%$,' as the bank's Web site says. But Grameen's performance in recent years hasn't lived up to the bank's own hype. . . . For the whole bank, $19 \%$ of loans are one year overdue."). But see Muhammad Yunus, Letter to the Ed., Credit as a Human Right, WALL ST. J., Dec. 12, 2001, at A19 (replying to Pearl and Phillips and asserting that "by December 2002, the repayment rate will reach $98 \% "$ ).

39. See Edward Chancellor, The Devil Take the Hindmost: A History of Financial SPECULATION 233-37 (2000) (describing the rise and fall of the U.S. and Japanese property markets during the past twenty years). The point is simply that real estate is not always such ironclad collateral. 
situations, the purpose of microcredit would be to provide credit that a rational credit market would provide but does not on account of irrational prejudice. ${ }^{40}$

Yet in either case of assumed market irrationality - unwillingness to consider nontraditional collateral or uncollateralized loans, on the one hand, or discrimination, on the other-if one purpose of microcredit is to overcome that irrationality, then presumably microcredit ought to be able to create a profitable niche, one that covers its costs, if the opportunities for profitable lending really exist and are simply being irrationally ignored by the existing market. ${ }^{41}$ Yet this has not typically been the experience of microcredit programs; typically they have not found a profitable, selfsustaining lending-to-the-poor niche that was irrationally ignored by commercial lenders. Perhaps this is due not to the profitability per se of the lending niche, but instead to the higher costs incurred by an outside microcredit lender, with higher costs associated with such things as overseas operations, etc. ${ }^{42}$ Still, the sobering experience of the microcredit community has been that even when the local operation is treated as a stand-alone, without imputing to it the higher costs of the larger microcredit program of which it may be part (particularly the costs involving foreign exchange), it is typically still not self-sustaining. This reality at least challenges what the meaning of market irrationality is; perhaps it does not describe irrational behavior by particular lending actors, into whose shoes an outside microcredit provider can profitably step, but rather a much more systemic, structural irrationality, such as a whole embedded system of discrimination against women and their ability to be equal economic actors. But that is not necessarily an irrationality on which a microcredit institution can turn a profit. ${ }^{43}$

A final conception of the fundamental purpose of microcredit might be whether the refusal of commercial lenders to lend to the poor might be largely a matter of transaction costs and the economies of scale of lending.44

40. For an account of the history of such discrimination in the United States, see Kenneth Anderson and Paige Mailliard, Women's Banks and Women's Access to Credit; Competition Between Marketplace and Regulatory Solutions to Gender Discrimination, 20 LOY. L.A. L. REV. 771 (1987)

41. As Peter Montagnon puts it, microlending has grown so large that the commercial markets cannot afford to ignore it.... For commercial banks, there may be an opportunity of broadening their customer base in the developing world. The food hawker in Manila may not be destined to become the Colonel Sanders of tomorrow; but many can reasonably expect to graduate to more conventional retail banking services....

MONTAGNON, supra note 7, at 5-6.

42. See generally ELISABETH RHYNE \& LONDA S. ROTBLATT, WHAT MAKES THEM TICK? EXPLORING THE ANATOMY OF MAJOR MICROENTERPRISE FINANCE ORGANIZATIONS 44-49 (1994) (ACCION International Monograph Series No. 9) (discussing considerations of productivity, operating costs, and viability of microcredit organizations).

43. See Anderson and Mailliard, supra note 40 (making a similar argument with respect to women's banks in the United States in the 1970s and 1980s).

44. For a case study approach to this issue, see GILBERTO M. LLANTO \& RONALD T. CHUA, Transaction COSTS OF LENDING to THE POOR: A Case STUDY of Two PHILIPPINE Non- 
Typical for-profit banking experience suggests that a lender's transaction costs in making, for example, a thousand dollar loan are not so different from those of a hundred thousand dollar loan-but the latter obviously generates much more revenue. 45 Such being the case, the function of microcredit provided by subsidized nonprofit lenders is to overcome the problem of economies of scale-that is, the fact that it is inefficient for a commercial lender to deal in such small amounts of money, even if the businesses undertaken by the poor are profitable. The businesses may be profitable, and of immense importance in raising family income of the poor, yet not be sufficiently profitable to overcome the opportunity costs posed by economies of scale in reducing on a relative basis the transaction costs of lending. Yet still, at some level, the transaction costs of bank loans reflect assessments of risk. The paperwork and other transaction costs would not be imposed by lenders if they did not think that overall they thereby increased their credit protection. In that sense, the transaction costs and economies of scale represent simply another way of saying that microloans are, dollar for dollar, riskier than other loans with traditional borrowers and collateral.

\section{Microcredit Interest Rates and NGO Self-Sustainability}

Each of these alternative ways of thinking about microcredit tends to be regarded by microcredit organizations as the most important way of conceiving of the purpose of offering microcredit in varying circumstances. In some places and situations, the dominant issue may be, for example, embedded discrimination against women, while in other situations the issue may be economies of scale, or any combination of these or other factors. Microcredit as a development strategy understands its role as having to address each of these three credit access problems - rational risk avoidance by commercial providers, irrational discrimination by commercial providers, and the negative effects of transaction costs and economies of scale on the amount of funds available for the poor. ${ }^{46}$ The

GOVERNMENTAL ORGANIZATIONS (Foundation for Development Cooperation ed., 1996) (attempting to identify and quantify components of transaction costs in microcredit).

45. To take one of many possible examples, Standard Bank, a commercial bank in South Africa,

started a micro-lending division in 1992 which built up a portfolio of R1.5 million in loans by the time the experiment was stopped in 1996. The problem was not bad loans - which were held below 4 percent of the portfolio-but the high level of operating costs. . . . To cover these costs required a high interest rates [sic]. Standard Bank officials reckoned they needed annual rates of between 50 and 100 per cent to make a reasonable return, well in excess of the Usury Act ceiling of 29 per cent on loans in excess of $R 6,000$.

MONTAGNON, supra note 7, at 10 (emphasis added).

46. The problem of economies of scale is, of course, a rational reason for not extending the credit to the poor. In that sense it is a subset of the rational rather than the irrational. It is listed separately because in practical terms it is quite different from the refusal to lend on account of the lack of tangible collateral. 
emphasis varies from place to place according to circumstance, but each of these can be taken as a reason why microcredit is needed within a poor community.

There can be no question, however, that a microcredit organization acts imprudently if, within the market in which it operates, it does not have a plain view as to why commercial credit is not available to its target population among the poor - why the local market has decided not to lend to this population. ${ }^{47} \mathrm{~A}$ microcredit organization ignores the judgment of the market at its peril, even if its conclusion is either that the market is irrational and is therefore missing a profitable opportunity, that there is a profitable niche that is insufficiently profitable to attract commercial capital but that microcredit can fill, or even that commercial capital rationally ignores the poor in this circumstance but that the opportunities for income growth among the poor make deliberately subsidized microcredit capital desirable nonetheless as a development strategy.

The peril that microcredit organizations face over the long term by not having clear reasons for lending where commercial markets do not is that their own uneconomic activity will cause capital to be depleted through expenses (including loan losses) in excess of revenues, eventually eating away at capital reserves and outstripping the usual sources of nonprofit capital such as philanthropic donations. In other words, the organization will simply find itself out of money and out of business. It has happened repeatedly in the history of microcredit providers; the history of microcredit is littered with the wreckage of programs that put themselves out business. ${ }^{48}$ This fundamental concern can be expressed as two interlinked economic questions which are more or less flip sides of the same coin, each of them at once intensely practical and yet indicative of the deepest conception that the microcredit organization has of its own activity and its relationship to the poor and to the market. On the one hand, what interest rate should a non-commercial provider of credit charge its clients among the poor? ${ }^{49}$ And, on the other, is it possible for a microcredit organization to be self-sustaining, in the sense of generating, as with a

47. As Ledgerwood says,

Ultimately, most of the dilemmas and problems encountered in microfinance have to do with how clear the organization is about its principal goals. Does [a microfinance institution] provide microfinance to lighten the heavy burdens of poverty? Or to encourage economic growth? Or to help poor women develop confidence and become empowered within their families?

LEDGERWOOD, supra note 7, at 4.

48. See LEDGERWOOD, supra note 7, at 4 (noting that "there have been many more failures than successes" in the history of microfinance). For a recent review of U.S. experience in microcredit, see Nitin Bhatt et al., Can Microcredit Work in the United States?, 77 HARV. Bus. REV. 26 (1999) (opining that while a few programs are effective, overall U.S. microcredit programs are tiny, inefficient, and ineffective); see also Marla Dickerson \& Lee Romney, Study Contests Micro-lenders' Effectiveness, L.A. TIMES, Nov. 3, 1999, at C9 (reporting that over 30 percent of the programs that were lending in 1996 had gone out of business two years later). See also Pearl \& Phillips, supra note 11 (discussing Grameen Bank's problems).

49. See CASTEllo, supra note 29. 
commercial bank, sufficient income to cover its costs and grow its portfolio-leaving aside the problem of paying back the initial investment in the microcredit organization itself-given its target client base among the poor? The link between the two questions is plain: self-sustainability is a function of revenues exceeding expenses (including loan losses), and revenues are a function of loan volume and interest rates charged on that volume. ${ }^{50}$

Obviously there is a rate of interest that, with sufficient lending volume, will make self-sustainability possible-provided, just as obviously, that there are enough entrepreneurs among the poor able to borrow and repay at such interest rates. Strikingly, given the heterogeneity of microcredit activity worldwide and the circumstances under which it takes place, the experience of microcredit providers has overwhelmingly been that poor borrowers can afford to pay interest rates at prevailing commercial rates. ${ }^{51}$ True, the prevailing local commercial interest rate is not necessarily the same thing as the rate needed to cover a microcredit organization's costs and so make it self-sustaining, partly for the reason that microcredit organizations come from outside the local credit market, and so their costs (the same as their ability to set interest rates at subsidy levels below local commercial rates) are independent of local commercial rates which must be adequate to cover local lender costs. But the local commercial rate is often taken as a benchmark interest rate, i.e., an interest rate which if charged does not alter the local credit market (which may be desirable or undesirable from the point of view of the microcredit organization).

Still, the best practices developed by leading microcredit organizations consistently urge charging market rates of interest; the strongly predominant view among microcredit experts is that the issue for the poor is not being able to pay a commercial interest rate (or even greater), but is having access to credit in the first place. 52 Of course, determining the prevailing commercial rate for activities of the poor that have not been the subject of long-term experience of default rates is not straightforward. It cannot be assumed, as microcredit practitioners sometimes do, that the commercial rate is the appropriate one, because the risks may not be the

50. As Maria Otero, President of ACCION International, has succinctly put it, "The sustainability of a microenterprise assistance program depends primarily on three factors: 1) high volume of lending activity; 2) appropriate institutional capacity to maintain and expand the program; and 3) adequate repayment rate." MARIA OTERO, MICROENTERPRISE ASSISTANCE PROGRAMS: THEIR BENEFITS, COSTS AND SUSTAINABILITY 24 (1989) (ACCION International Discussion Paper No. 2).

51. Otero and Rhyne point out that although traditional loan programs "have been reluctant to charge full-cost interest rates to microenterprises ... [i]n most countries, there is a large difference between commercial rates of interest and rates charged in the informal financial sector. Microenterprise programs can charge much more than formal financial institutions and still underprice informal-sector alternatives." NEW WORLD, supra note 26, at 20 (emphasis added).

52. As Otero and Rhyne emphasize, "microenterprise borrowers are far more sensitive to the availability and convenience of credit than to the interest rate." Id. at 20. 
same. ${ }^{53}$ Still, given that the early practice of microcredit had assumed that interest burdens, rather than access, would be a significant hurdle in making loans to the poor-which led early lending programs to offer highly subsidized interest rates such as $2 \%$ interest as compared to commercial rates of $20 \%$ - the discovery that microcredit borrowers often can successfully borrow at commercial rates (whatever the actual commercial rate that should be charged to microcredit borrowers) is an important fact about the poor and their ability to create profitable enterprises.

Even when microcredit loans are made at approximately commercial rates, however, microcredit organizations only very rarely succeed in covering their costs; self-sustainability is much more the extraordinary exception than the rule for microcredit organizations. ${ }^{54}$ Sustainability, however, for a long time has been the Holy Grail of the microcredit community. ${ }^{55}$ Why? Because it implies, first, at the level of strategic vision, being able to self-finance growth out of poverty from revenues of the poor communities themselves, the poor bootstrapping their own communities out of poverty, the grandest lessons on capital accumulation applied to poor communities.

Second, at a less grandiose level, sustainability means that a microcredit organization succeeds in untying itself from the eternal round of fundraising among governmental and philanthropic donors because its costs are covered by its own lending activities. In today's world, philanthropic funds seem increasingly to follow rapidly shifting winds of fashion (at least, from the standpoint of fundee organizations seeking to

53. "Commercial rates," as Castello et al. point out, "are rarely if ever available to microentrepreneurs ... . [E]ven if microentrepreneurs had access to banks, they would not have access to commercial rates." They would pay a rate far closer to moneylender and other informal sector alternatives. CASTELLO, supra note 29 , at 11 n.3.

54. As a leading expert, Francisco "Pancho" Otero, has said,

Sustainable microfinance. On the face of it, a simple fundamental idea that is so basic in its crudest form .... Lend poor people capital and build up your portfolio with them as they build up their deposits with you. While you are at it, cover your costs and, in time, make money. So, if it so simple, why is sustainable microfinance so rare? Why are failures so common and so spectacular? . . Our understanding of microfinance in its sustainable version is not all that thorough. Otherwise, the thousands of initiatives that have sprung up in the past 10 years would have grown and flourished much faster than they have, and failure, as well, would not be such a commonplace occurrence.

Francisco "Pancho" Otero, Introduction, in CONVERSATIONS, supra note 22, at $i$.

55. Michael Chu, former president of a leading microfinance organization, ACCION International, maintains that a "program dedicated to the poor can grow to the point of paying for all its costs, capital included." MICROCREDIT SUMMTT REPORT 17 (Feb. 2-4, 1997). Likewise, Ledgerwood says that "the goal of sustainability (cost recovery and eventually profit) is the key not only to institutional permanence in lending, but also to making the lending institution more focused and efficient." LEDGERWOOD, supra note 7, at 2-3. For an important critique of the ideal of sustainability, see Thomas W. Dichter, Appeasing the Gods of Sustainability: The Future of International NGOs in Microfinance, in NGOS, STATES AND DONORS: TOO CLOSE FOR COMFORT? 128 (David Hulme \& Michael Edwards eds., 1997) (arguing that the focus of NGOs on sustainability distorts the mission of international development). 
raise money). ${ }^{56}$ The cool cause of today is forgotten tomorrow, leaving the wreckage of investment in half-completed programs in the wake of funding that-something like the hot money flows of the Asian currency crisis-shifts on a dime to some other cool cause. ${ }^{57}$ Since NGOs are typically built around a particular mission or kind of activity, they have only limited abilities to credibly reinvent themselves as the new thing in philanthropy when patterns of funding shift. Having independent sources of funds is a precious gift that, at least in some measure, microcredit might offer.

In the actual experience of microcredit, of course, matters are not so grand or extreme. Despite early claims in the history of microcredit in its triumph list phase, so to speak - that credit was all the poor really needed to finance themselves out of poverty - today there is practically universal agreement that microcredit cannot replace direct public investment in education, health care, and other basic social infrastructure for the poor. Microcredit is a complement, not a substitute. Likewise, even microcredit organizations that seek self-sustainability typically only measure it with respect to the local organization or office, rather than counting the costs of the full organization, with expensive staff and offices in foreign capitals. Moreover, when assessing sustainability, they rarely if ever take into account initial contributions of capital by donor agencies that, in theory, would have to be repaid at an appropriate discount rate. Moreover, these organizations do not see self-sustainability as a reason to cease fundraising and other attempts to draw outside capital into themselves and the poor communities they serve. On the contrary, they see the possibility of sustainability in some measure as a means to draw further outside funds into these communities; successful microcredit lending unsurprisingly tends to attract further funds from donors eager to fund winners in the market, so to speak, of NGOs. ${ }^{58}$

"Credit," "repayment," "interest rates," "risk," "rates of return," "collateral": this, of course, is the terminology of banking. In many cases, though, venture capital would be a more accurate term for microcredit activities, which often involve close and active monitoring, indeed managing, of what the client is doing with funds. In fact, the question of whether microcredit should be modeled on banking, with its traditionally passive lending and collection of fixed interest, or on venture capital, with its emphasis on active management of the company portfolio and taking of returns commensurate with risk through equity stakes, reveals another significant economic issue for microcredit as it seeks commercial role

56. See, e.g., David Hulme \& Michael Edwards, NGOs, States and Donors: An Overview, in Hulme \& Edwards, supra note 55, at 3-22 (discussing effects of donor preferences on NGO activities).

57. See Anthony Bebbington \& Roger Riddel, Heavy Hands, Hidden Hands, Holding Hands? Donors, Intermediary NGOs and Civil Society Organizations, in Hulme \& Edwards, supra note 55, at 107 (criticizing the role of donors in setting NGO agendas).

58. See Christine W. Lett et al., Virtuous Capital: What Foundations Can Learn from Venture Capitalists, 75 HARV. BUS. REV. 36 (1997) (noting that charitable foundations can learn from venture capitalists how to determine winners and losers in the conduct of charitable activity). 
models for itself. ${ }^{59}$ Microcredit takes risks and often engages in monitoring and supervision of investments that, if done in commerce, would tend to be associated with the higher risks and costs of venture capital, while the payoff of microcredit-in the form of fixed interest rather than a percentage of the profits - is limited to that of traditional banking. ${ }^{60}$ This may in the long run be a dubious combination for many microcredit organizations, or it may at least turn out to be a combination which requires greater subsidy than otherwise would be required if microcredit organizations captured equity-type returns rather than merely fixed-debttype returns.

But whether the model is really banking or venture capital, it is nonetheless fundamentally that of the market, yet microcredit is an economic activity undertaken where the commercial markets, for whatever reasons, do not operate. Therein lies a tension and contradiction that has potent implications both for the theory and practice of microcredit. While it might seem a merely theoretical concern whether microcredit corrects market failure or simply subsidizes commercially uneconomic but socially desirable activities, the answer governs in practical fact how far microcredit organizations can extend their programs and how many of the poor they can serve over the long run. ${ }^{61}$ The question, in other words, is vitally practical. Indeed, one of the most interesting commentaries on microcredit is titled, "What microenterprise credit programs can learn from the moneylenders." 62 It underscores the awareness of experienced microcredit institutions of the risks of departure from commercial equilibrium in the provision of credit, risks inherent in NGO-provided

59. For a discussion of differences between venture capital and other more passive forms of investment, such as banking, see generally JOSH LERNER, VENTURE CAPITAL AND PRIVATE EQUTTY: A CASEBOOK 1-6 (2000).

60. I chair the board of directors and serve as general counsel for a nonprofit venture fund, the Media Development Loan Fund (MDLF), which makes investments into for-profit media in countries around the world to strengthen the "independent" media sector (media not controlled by government, political parties, or criminal enterprises and which provides significant and objective news coverage). It is not precisely microfinance because the scale of investments runs from hundreds of thousands to millions of dollars, and the social purpose is not about poverty directly but about freedom of expression and transparency. However, it bears many financial similarities to microfinance in that the economics are much the same, and in our experience the largest question related to sustainability is whether to adopt the model of banking or of venture capital risks and returns. The banking model, it is clear, will not produce sustainability for MDLF.

61. The most ambitious plan for increasing the number of poor served by microcredit to reach 100 million of the world's poorest people is contained in the Microcredit Summit Declaration and Plan of Action. It is a plan that calls for increased amounts of funds from every source, whether governments, international agencies, foundations and other philanthropic sources, or the commercial sector. MICROCREDIT SUMMTT DECLARATION, supra note 21. Montagnon, however, in an astute analysis of the funding question, urges that if serious funds are to come from the commercial sector - the only largely untapped source of funds-those funds will only be provided on a for-profit basis. He concludes that it is probably best to bifurcate the microcredit sector into programs that are gradually moving away from subsidized funds toward integration into the commercial sector and programs that will always require subsidy. MONTAGNON, supra note 7, at 31-32.

62. Robert Peck Christen, supra note 30. 
microcredit, even when that commercial equilibrium declines to provide credit to the poor.

\section{Microcredit and Market Principles}

If microcredit is fundamentally credit deployed for social purposes but subsidized by non-commercial sources, whether governmental or philanthropic, in circumstances where commercial markets would not lend, it is therefore something that is not precisely a market activity but one which nonetheless emulates the market in key ways. What are some of those ways? We can identify five at least:

First, microcredit uses market mechanisms in its provision of credit and capital to the poor. After all, the intention of microcredit programs is to lend money to the poor that (notwithstanding various subsidies built into microcredit programs) is to be repaid with some amount of interest. The funds are not simply given away in the form of grants. Microcredit programs have a variety of means of enforcing repayment discipline; in some programs, such as the Grameen Bank's famous lending circles, the borrowers, usually village women, form a group that uses peer and social pressure to enforce payment; in some programs the group as a whole is responsible for unpaid loans, while in others lending proceeds serially, so that the next borrower can obtain funds only if the previous borrower has repaid them. ${ }^{63}$ In other situations, actual legal mechanisms are brought to bear. ${ }^{64}$ Repayment mechanisms among the poor are striking in three respects from the standpoint of the business regulation. To start with, given the inefficiency of using legal mechanisms to enforce collection of tiny amounts of fifty or hundred dollars, repayment mechanisms rely instead on the threat of not granting loans in the future. Microcredit programs very often rely on repeat players for loans, rather than one-off loans, in part because growing familiarity with a particular borrower's risks increases confidence in collection and pricing of loans and thus lowers monitoring costs.

In addition, given the inefficiency of legal mechanisms, microcredit programs frequently rely on the pre-market culture of traditional society among the poor for whom the repayment of a loan is seen as a paramount social obligation rather than merely as a market decision based on rational considerations and opportunity costs. ${ }^{65}$ It is noteworthy how often repayment works best among village settings in which repayment of obligations is a matter of social honor and much less well, for example, in

63. See YUNUS, supra note 8, at 105-17 (describing the mechanics of joining a lending circle of the Grameen Bank).

64. A large-scale nonprofit venture fund such as MDLF, with large loans at risk to commercial entities, will utilize formal legal mechanisms to enforce loans.

65. In Grameen Bank relationships, "[ $t]$ here is no legal instrument between the lender and the borrower. We feel our relationship is with people, not with papers. We build up the human link based on trust. Grameen succeeds or fails depending on how strong our personal relationship is with the borrowers." YUNUS, supra note 8, at 110. 
atomized urban communities, where honor in fulfilling obligations is not publicly at stake within a community in which one is known.

There is a certain irony in the dependence of microcredit, at least in some instances, on thoroughly non-market forms of obligation, rather than the classic capitalist notion of legally enforceable contract, as the mechanism of repayment.66 Moreover, as several observers have noted, these mechanisms of social obligation are often very coercive indeed, especially with respect to women, in part because culturally they often take their own obligations more seriously than men do and because they also take them more seriously vis-à-vis other women in their borrowing circle. ${ }^{67}$ One microcredit practitioner in Latin America once remarked to me that his organization strove to maintain a steady minimum of women in each borrower's group, because in its experience men took the obligation to repay so much less seriously than women. ${ }^{68}$

Finally, the use of joint and several liability whether in a strictly legal sense, under written contract, or in a practical sense, as in making a borrower's circle jointly and severally liable for debts of the group as a condition of new loans, runs in some sense exactly opposite the direction of enterprise law in such places as the Unites States. Indeed, the trend in the United States has been to allow a wider range of entities to operate with limited liability of owners from demands of their creditors through such trends as the development of limited liability companies. In effect, of course, the promise of joint and several liability aims to overcome a chief difficulty of the poor in obtaining credit-lack of collateral-by pooling together the creditworthiness of a group of borrowers rather than relying on the creditworthiness of a single borrower.

Although this use of lending and repayment with interest has been described as a market mechanism, it might in fact be queried in what sense it is a matter of the market. The mechanism for extending credit seeks, in some sense, to substitute for a (non-existent) commercial market, but is the provision of microcredit a market mechanism in the sense of allocating scarce resources through supply and demand and, ultimately, price? It seems evident that in this sense, at least, microcredit programs are not typically market-driven since they do not ration the credit they offer through raising or lowering interest rates or other pricing mechanisms. Supply and demand of lending capital is not typically a constraint on microcredit organizations; typically they have plenty of money to lend (given the tiny size of the borrowing requirements of the very poor) and are not themselves constrained in dealing with the very poor by limits on capital for lending. Their constraints are fiscal and lie in the costs of

66. See Shari Berenbach \& Diego Guzman, La Experiencia MuNdial de los Grupos SOLIDARIOS (1993) (ACCION International Serie de Monografias No. 7) (discussing the experience of using solidarity circles in microcredit and their connection with pre-existing relationships especially among village women).

67. White, supra note 25 , at 332.

68. Interview with Roberto Eisenman, President, MiBanco, in Panama City, Fla. July 1999). For a contrary view, see CONVERSATIONS, supra note 22 , at $39-40$ (remarks by Rosalind Copisarow). 
administration in all its many guises, especially in an activity in which it is not strange to have transaction and monitoring costs exceed the principal, let alone the interest, on a microloan.

These costs reflect in part the uneconomic nature of running what amounts to an international venture capital fund (if one considers the full size of microcredit organizations and their alliances and vertical business partnerships with their donors). The fund operates in dollars or other hard currency but is invested in tiny, local, micro-lending operations in which a hundred dollar loan may be large and moreover earns such interest as there is in local currencies. It is as though (exaggerating deliberately) the international resources of Citibank private banking were put behind hundred dollar loans to rural farmers in a village in Brazil. Indeed, perhaps surprisingly, adequacy of lending capital is so little the issue that a frequent complaint of microcredit organizations is the difficulty in finding enough borrowers willing to meet lending criteria, and a frequent activity of microcredit organizations is to seek out borrowers. ${ }^{69}$ The difficulty lies in part in the obstacles and transaction costs involved in forming borrowing circles and other mechanisms, such as joint and several liability, that seek to create substitutes for collateral. Nevertheless, the fact that microcredit organizations demand repayment rather than simply offering grants of funds is some indication of imposing on borrowers the fact of scarcity of resources, and in that sense at least, microcredit adopts a market approach.

Second, not only is the mechanism for providing the poor with capital at least in some important respects a market one, the intention is that the poor use the capital thereby obtained toward market ends. ${ }^{70}$ The purpose

69. One director of a microfinance bank in Latin America told me that, far from lack of capital, the problem is one of training enough staff who can go out and engage in the strenuous activity of finding borrowers. This is very far from a for-profit bank, where you can expect the customers to come through the door.

70. There is a debate as to whether microcredit ought necessarily to aim at microenterprise, that is, at business enterprise. Stuart Rutherford of SafeSave emphasizes that microenterprise is only one reason for the existence of microfinance institutions or, more broadly, banking services for the poor:

I have a very simple view of what financial services are, which comes from something like 35 years of observing how poor people handle their money .... And what that experience boils down to is this: that poor people have a capacity to save, small though it is, but poor people also very frequently during their lives need large sums of money, larger than they normally have about them. The only way they can reliably get hold of these sums is by finding some way of exchanging them for their capacity to save.... So, swapping small sums for big sums is basically what financial services is all about.... There are three basic kinds of big sums that poor people need. They need some big sums for life-cycle events-getting married, burying their grandparents, educating their kids. The second big category is emergencies.... And then the third category is opportunities ... to set up a business, to expand an existing business.... A lot of microenterprise lending programs focus on that third category of lump sum, the opportunity to set a business, or expand an existing business .... But in my experience, that's often a minority use. The other uses I mentioned are more demanding on them, and their 
of microcredit is to enable the poor to engage in market activity themselves, creating small or micro businesses of one kind or another. What the poor are to do with their capital is buy, sell, and add value through their labor, so as to profit and increase family income. The purpose, in other words, is that they use their borrowed capital to enter into market transactions as producers and not merely as customers. In this sense, microcredit is highly market-oriented. Questions have been raised about the overall social efficiency of providing capital for the very poor to create a plethora of microbusiness. It is not always evident that the businesses serve any purpose other than to trade items around the community of the poor without generating substantial new income. This possibility of inefficient activity that would not take place but for the subsidized funds provided by microcredit organizations themselves is one example of the risks of microcredit distorting local markets. On the other hand, it has been noted that many services of a relatively modest kindbicycle repair or shoe repair, for example-are often not provided within poor communities themselves, even though there are strong grounds for thinking the activity to be economically sustainable, since even poor people spend money on such services but must go outside the local community to do so. Microcredit sometimes enables individuals to start providing such services within the local community, at a net welfare gain in part because income turns over within the local community and in part because it is more efficient to offer and obtain such services close to home.

Third, the fact that a high percentage of capital deployed in microcredit programs comes from the world's richest countries and goes to the world's poorest means, in some sense, that microcredit is a global transfer of resources from rich to poor. Microcredit seeks to foster principally local markets for goods and services produced by the poor. (Sometimes microcredit seeks to create genuinely transborder markets for those goods, such as the sale of artisanal, indigenous, or folk art to the rich Western world, usually through intermediaries but even sometimes directly over the internet, but this obviously is much more the exception than the rule.) The provenance of its funds, however, means that it is in some respects a form of foreign direct investment, insofar as it represents foreign organizations using lending capital to act with local poor people to create new enterprises. If one views much microcredit on a venture capital model, microcredit organizations, because of their active role in monitoring and management in many cases, look more like partners than passive lenders, and so the model starts to resemble foreign direct investment. ${ }^{71}$ And foreign direct investment is, after all, a sine qua non of economic globalization and the free flow of capital..$^{72}$ In this respect, microcredit is

need to get lump sums to cover those needs is more frequent. . .

CONVERSATIONS, supra note 22 , at $4-5$.

71. Foreign direct investment "is defined as equity investment by a parent firm to control the operations of a subsidiary corporation in another country." ALAN RUGMAN, THE END OF GLOBALIZATION 1 (2000).

72. As Rugman says, foreign direct investment is the engine that drives international 
not merely committed to emulating the market in certain ways, but it is committed to and part of a global market in its own capital flows, even though microcredit's capital often flows through the mechanisms of philanthropic and governmental funding (in other words, the nonprofit capital market).

Fourth, as already noted, an explicit aim of microcredit has always been to get development aid directly into the hands of those who need it most and to avoid flowing it through the hands of corrupt and inefficient governments and government officials who often siphon off large amounts of it. In this sense, the culture of microcredit evinces a certain skepticism about government that is also sometimes present in global market ideology. One does not, however, want to overstate this point. Microcredit organizations and their staffs vary widely in their attitudes toward government and governance, and my own experience suggests that nearly all favor the creation of welfare state mechanisms for the very poor alongside microcredit programs because their experiences have taught them that markets and microcredit alone are not remotely enough to permanently affect the life chances of the poor. ${ }^{73}$

Drawing on my own admittedly subjective experience, microcredit as an activity sometimes has the support of politically conservative supporters of market ideology who take microcredit to be, almost by definition, a kind of slap in the face at government, a championing of market mechanisms over governmental ones for relieving poverty. Microcredit practitioners (again in my experience) rarely if ever hold the view that to embrace market mechanisms is to reject governmental solutions to poverty; they reject corrupt and inefficient government, not government itself. Indeed, since so much of the funding for microcredit comes from the development agencies of rich countries, such as the Nordic countries, Canada, the Netherlands, and Japan, it might be more accurate to say that microcredit seeks to substitute not market mechanisms for governmental ones, but instead the governmental agencies of certain rich countries (because of their efficiency, incorruptibility and accountability) for the governments of certain poor countries, and that microcredit organizations act as an intermediary in this substitution of governance. Or in other words, a certain form of globalization is at stake here but rather than the economic globalization of the global market, it is one form of political globalization and the substitution of one institution of governance of the poor for another, through the transnational mediation of microcredit

business. Id.

73. At the Microcredit Summit, Federico Mayor, Secretary General of UNESCO, noted that if we are to build on the remarkable achievements so far, microfinance must be complemented by supporting programs in the fields of education, health, and other essential services. MICROCREDIT SUMMIT REPORT, supra note 55, at 15. Similarly, Fawzi al-Sultan, president of the International Fund for Agricultural Development, stated that "[w]e must nonetheless keep in mind not only the benefits but also the limits of microfinance as a tool.... It is not enough by itself to ensure sustainable development for the rural poor .... The poor equally need access to better technologies, to health and education services, to fair markets and adequate infrastructure." Id. at 27. 
organizations. ${ }^{74}$

Fifth, and finally, during a certain early triumphalist phase of the microcredit paradigm's growth, proponents proclaimed that if given a generous investment of initial capital, microcredit could turn international development work into a virtuous circle of investment in new enterprises by the poor, followed by repayment of investment, and then reinvestment in additional new enterprises. It is the dream, in other words, of solving the problem of poverty through the mechanism of capital accumulation, bootstrapped by the poor themselves from their own resources but kicked off with an infusion of outside funds. Michael Chu, president of the leading microcredit organization, ACCION International, stated at the Microcredit Summit that "the vanguard of microcredit has proven that this activity of enormous social impact can be managed to achieve economic viability." 75 Chu meant by this that microcredit organizations would be self-sustainable and the poor would be bootstrapped out of poverty through cycles of capital accumulation and reinvestment.

The concrete expression of this aspiration, however, has sometimes come in the form of a particularly seductive exchange between a microcredit organization and its donors. A microcredit organization, feeling that the donor is losing interest in microcredit for whatever reason, asks to the donor to make a large single capital grant, which, through the mechanism of microcredit, will theoretically turn over indefinitely if not grow into something larger. It is not clear how often the donor actually believes this plea for funds, but if it is seeking to leave the microcredit funding field, this is a convenient rationale for doing so, because its grantee organization is in effect saying, make us a single large grant and we will not come ask you for money anymore. ${ }^{76}$

The problem, as already noted, is that self-sustainability rarely if ever occurs. Likewise, the promise of grand capital accumulation and reinvestment as a way of relieving poverty, at least insofar as microcredit agencies are the agents of accumulation and reinvestment, will never be fulfilled. The source of poverty is not simply a lack of credit and capital among the poor; this has been overwhelmingly recognized within the microcredit community as it has backed away from grandiose claims of being poverty's silver bullet. On the contrary, the consensus of the microcredit community today is that microcredit and market mechanisms are merely one tool for ending poverty, to be used alongside large-scale social investment in education, health, etc., and straight-out income transfer from rich to poor. These investments and expenditures cannot be financed out of the resources of the poor but instead only out of the gains of global markets, rich and poor and in-between, taken as a whole.

74. See Malcolm Waters, Globalization 7-8 (1995) (discussing formal differences between "economic" and "political").

75. MICROCREDIT SUMMIT REPORT, supra note 55, at 16-17.

76. I speak here from the personal experience of having been on both sides of this exchange in many organizations over the years, sometimes with the funders and sometimes with the fundees. 
Taken together, even with the reservations noted, microcredit indeed seeks to emulate and operate according to market principles. In some respects it can even be understood as participating in the global flow of capital, within the restricted (but much larger than one might have thought) flows of the transnational nonprofit capital market. True, it is still not evident whether and to what extent microcredit is committed to global markets and economic globalization. Being committed to market principles in local markets is one thing, while being committed to the terms of global markets is perhaps another. For now, however, it is enough to have shown a certain affinity for market principles.

\section{MICROCREDIT AS EXTENSION OF OR SUBSTITUTE FOR GLOBAL MARKETS?}

\section{A. The Universalist Moral Claims of Globalizing Markets}

Some might find it strange or hypocritical to speak of the moral claims of global markets, let alone to think that they might have something to do with the moral principles of international NGOs involved in microfinance, notwithstanding that microfinance providers plainly take a good deal of their principles from the practical morality of the market. Yet, as already noted, the arguments made forcefully in favor of economic globalization are typically made not merely from inevitability, nor even from simple utility for the greatest number, but from the Rawlsian principle of benefiting the worst off. It is precisely because both sides in the debate over economic globalization think that not merely efficiency but justice and welfare are at stake that the debate is pursued so vigorously. It is the claim of justice, and not merely inevitability, that fires Thomas Friedman's The Lexus and the Olive Tree. Likewise, it is the claim of justice in the face of seeming inevitability that fires Jeremy Brecher and Tim Costello's Global Village or Global Pillage: Economic Reconstruction From the Bottom Up. ${ }^{77} \mathrm{~A}$ version of the moral claim that economic globalization can and must be made to benefit the world's poor comes, strikingly, from U.N. Secretary General Kofi Annan. Annan spoke a few months after the Seattle protests that scuttled meetings of the World Trade Organization in 1999, before a group of NGO activists who, while they might not have protested in Seattle, at least had significant reservations about the direction and consequences of economic globalization. To them Annan said:

[T] he overarching challenge of our times is to make globalization mean more than bigger markets... while globalization has produced winners and losers, the solution is not confrontation. It is not to make winners of the losers and loser of the winners. It is

77. FRIEDMAN, supra note 9; JEREMY BRECHER \& TiM COSTEllo, Global Village OR Global PILlage: ECONOMIC RECONSTRUCTION FROM THE BOTTOM UP (2d ed. 1998). 
to ensure that nobody sinks, but that we swim together with the current of our times. ${ }^{78}$

Annan here accepts that economic globalization is, in the broadest sense, inevitable. It is the current of our times. The problem of policy is not to try and make economic globalization go away; it is to manage it in order to ensure that everyone win from the reality of economic globalization. Annan does not propose that this will happen automatically; it will require, in his view, political management. But he goes much further and, in his speech, tells the assembled activists that the world's poor are poor not because of too much globalization, but because of too little - because they are not part of it, because they are excluded. ${ }^{79}$

Economic growth is the only way out of poverty for the world's poor, and global markets are an indispensable part of that solution. Moreover, economic growth is, for Annan, the only way in which the poor have an opportunity to participate in the growth and in the ownership of a stream of that growth, and not merely to receive some bit of its redistribution as an afterthought by the wealthy, the leftovers of the rich. In this sense, then, Annan endorses the view that the global market is the answer to the moral problem of global poverty in the midst of globalization. It is within our power, Annan declares, to extend the new opportunities of globalization to all. Global capitalism, according to Annan, is the spirit of the age and the only way to create the economic growth without which the poorest in the future will be those left out of the grand spiral of wealth creation and the accumulation of capital..$^{80}$ In this sense, the current of our times, the global market, is more than something that simply must be accommodated. It is a necessary part of the economic engine by which the poverty of the world can be overcome.

Properly deployed, therefore, economic globalization can serve as part of the means by which to answer the just claim of the poor. And what is that claim, according to Annan? Not merely a claim upon resources, a claim upon the wealthy to transfer income, but instead a claim not to be left out of economic globalization, not to be left out of the market itself, and above all not to be left out of the cycle of wealth creation, ownership of wealth, and ownership of the means of production.

Another way of stating this claim is to say that the global market proposes to be universal not merely in a descriptive sense of the economic system that the planet uses, but in a normative sense of that system which ought to obtain. Annan seems to accept the virtue of the global market because it appears to be necessary to create the economic growth that can bring people out of poverty. In that sense, it is universal because it ought to be the economic system toward which we all aspire. To the extent this proposition is believed, as Annan seems to believe it, it potentially operates

78. Kofi Annan, Address to the Millennium Forum (May 22, 2000), available at http://www.globalsolidarity.org/artmilfor.html (visited Sept. 30, 2001).

79. Id. (emphasis added).

80. Id. 
as a powerful ideological force in bringing forth the global market. Markets operate in an embedded social, moral, and ideological system and so are combinations of both interests and ideals. Ideals matter in the spread of global capitalism, and one powerful ideal is that globalization serves everyone's interests, even if unequally.

But part of Annan's point is that the moral weight attaching to this normative universalism ought to attach only insofar as global markets really are universal. This is the force behind his reply to the NGOs doubtful of economic globalization: what the poor need is not less but more globalization, economic globalization that draws them into the global market where they can benefit from it. Annan's response to suspicious NGOs is in effect a challenge to the global market to make good on its promise to be global. The universal economic system has a moral obligation to be universal, to ensure that no one is left out, because those who are left out are, in Annan's view, left behind. If, in other words, global capitalism wants to benefit from the presumption that it does serve everyone's interests around the world, rich and poor, in one locale or another, then it must ensure that it is universal and that no one and no place is left out.

\section{B. The Poor and the Very Poor}

This call for global capitalism to make good its promise of universalism and include everyone within its jurisdiction raises an important question about the nature of the global market and the poor and recalls us to microcredit as well. It is the question of whether the global market really is universal in the sense that, as the technological essentials of telecommunications and transportation are brought within everyone's reach, and as local markets find an equilibrium within larger global markets, efficient activity would cause everyone to be deployed under its umbrella or, instead, whether some people would always be left out of the market, because it simply is inefficient to utilize them and their production.

We might illustrate the point by drawing a distinction between the poor and the very poor of the world. With respect to the poor, at the upper range of the income ladder of the poor, they perhaps work in low wage work of one kind or another, producing clothing or footwear or other commodities for the rich countries. They are part of the global market but do not do very well within it. One can debate whether international trade treaties should enforce minimum wages (e.g., the much discussed living wage) and other conditions to improve their terms within the global economy or whether such impositions will simply leave more of them unemployed. ${ }^{81}$ Their situation is important, but for the discussion here, I

81. See, e.g.., Globalize This! THE Battle Against the World Trade Organization AND CORPORATE RULE (Kevin Danaher \& Roger Burbach eds., 2000) (arguing against unregulated free trade). 
will put their issues off to one side. ${ }^{82}$

With respect to the world's very poor, however, matters are quite different. The chief characteristic of the very poor is that they have no place within the world economy. Seen from the standpoint of Annan's call to extend globalization to the poorest, their tragedy and disaster is that they are too poor to even be part of globalization. Put baldly, the world's poorest are too poor, too unskilled, too remotely situated, too difficult even to exploit within the world economy. Even their exploitation would not be efficient; it is not worth the trouble. Likewise, demands by protestors in rich countries for a living wage, for example, will not help them, because these people (often taken as the world's poorest $20 \%$ in income) are often not important participants in the wage economy. The fact-it is an ugly one, and one that needs to be made in an ugly way to make clear its moral tragedy - is that from the standpoint of the rich countries, it would be a net gain if the bottom $20 \%$ of the world's population could be sent off into outer space never to return and their now-empty lands turned into something pleasing to the world's bourgeoisie. The disappearance of the world's poorest would not have any impact on living standards of the rich. It would not deprive them of necessary consumers. If done neatly, it might all be rather a great relief to the rich. AIDS in Africa, of course, might yet do it, but of course in an appallingly messy way.

Hence the question is of what the moral universalism of global markets is understood to consist. Is the universalist moral claim of global markets that they will (eventually at least) draw in the very poorest to participate in them, that this will simply happen over time? Or is it that universal really

82. But microcredit, according to many practitioners, including Vijay Mahajan, head of Basix, a microcredit organization in India,

is not a poverty-relief strategy, particularly if you're talking about the hard-core poor, or the so-called poorest of the poor. They need other help before they need microcredit-help with health, education, nutrition, housing, things like that. Unfortunately, microcredit is being offered as a panacea for the poverty problem, and I disagree with that. It is certainly helpful for a whole range of poor people, including some of the poorest of the poor, but those people have to be a bit entrepreneurial and reasonably well endowed with human skills. And the poorer you are, the less likely that is.

CONVERSATIONS, supra note 22, at 2 . Moreover, adds Rosalind Copisarow with respect to the origin of the Microcredit Summit's emphasis on the poorest of the poor:

The origin of the summit was an organization called Results, which was-before it ever heard of microenterprise finance-interested in worldwide poverty alleviation, specifically by means of hunger alleviation. And the reason they're important is because they were the first organization to try to pull together a worldwide community of microfinance practitioners. And they happened to have, as their own slant, a view that the poorer the client, and the more hungry, the more legitimate the microfinance operation, because it was working toward the goal of alleviating poverty by alleviating hunger by making loans.

Id. at 39-40. This is an important debate within the microfinance community. This Article speaks in terms of the poorest of the poor as well as the merely poor, consistent with the Microcredit Summit Declaration, which is the most important document in the microfinance movement today. But the discussion in this Article would generally apply equally well to the poor as to the poorest of the poor. 
means most, and that the universal economic system will find it efficient to leave twenty percent of the world's population out, neither rewarded nor exploited, but largely untouched and in terrible poverty relieved only by the charity of those who get richer in global markets? Or, finally, is it that universal means that, efficient or not, global markets have a moral obligation to do what is necessary to draw even these otherwise untouchables into the system, as producers rather than merely as consumers of the charity of the rich? It should be noted that the last possibility is not merely about income transfer from rich to poor; it is about the transformation of the very poor into producers within a global market sense. It may very well mean, for that matter, their transformation into exploited poor workers within the global economy.

\section{Microcredit as Extension of or Substitute for Global Markets?}

One way, therefore, to understand microcredit is by how it regards the relationship between the poor and global markets, by reference to the three possibilities described above: efficient integration, efficient exclusion with wealth transfer through charity, and inefficient but morally compelled integration. It is not the only and certainly not the whole story of microcredit, but it does have the virtue of situating microcredit in relation to economic globalization, in relation to what Annan calls the current of our times.

If the first possibility were true, then microcredit might simply be thought to be unnecessary within the gradual action of global capitalism. Even the very poor would eventually be brought within the ambit of economic globalization, and no one would be left outside the market. Let us assume that this is not in fact likely to happen, or at least not fast enough to satisfy us. The market, working through the invisible or visible hand, is not likely all by itself to bring the very poor even up into the ranks of the merely poor. What then can be said of microcredit and the other two possibilities?

If the third possibility were true, then microcredit could perhaps be seen as a mechanism for calling upon global capitalism to do its moral duty and draw the very poor up into it. Microcredit could be seen, metaphorically, as a subsidized means of extending the ladder of the global market downwards into the ranks of the very poor, so as to pull them up into the social and economic life of the market. Microcredit assistance, from this perspective, could be seen as a means by which the very poor could achieve necessary capital, a toehold in the market economy, and the skills necessary to become participants in the universal economy. Microcredit could be seen as a means by which globalization makes good its obligation to provide something for everyone, even those who, absent some kind of assistance, would not efficiently be drawn in by the market. Put another way, microcredit could be seen as a mechanism that completes 
the moral task of economic globalization and so makes good its promise of universality. ${ }^{83}$ It completes global markets by including those people who, all other things being equal, would be left out of them. It completes the global market's moral obligations by not accepting the excuse that certain people are efficiently left outside and by instead presuming that they too must have a place-as producers, even micro-producers - at the table of global markets.

Of course this picture of microcredit assumes several things. One is that there be a sufficient connection between the extraordinarily local markets in which microcredit borrowers typically operate their microbusinesses and global markets to say that in some sense microcredit actually "completes" global markets and their universalist moral claims. It might be thought that, to the contrary, the local markets of the rural village or the socially isolated poor urban neighborhood are so separate from the global economy that whatever principles microcredit uses, the exercise cannot meaningfully be said to have anything to do with global markets.

But is this so? The world's poorest people, even in the isolated rural village, would appear to be subject to pressures, at least, from global markets. They are not insulated from global markets, even when they fail to benefit from them. Insofar simply as their interactions are monetized, for example, they are subject to potentially considerable pressures of inflation. Even insofar as they or others within their circles of exchange use imported goods (which of course is the norm even in remote villages today), they are subject to the risks of foreign exchange. Even among the poorest, the conditions of the global market impinge through currency and prices of exchanged staples and so on. In this particular sense, no one is "outside" global markets. The question, however, is whether and how the very poor can be drawn directly into the benefits, as well as the direct and indirect insecurities, of global markets. Microcredit, particularly insofar as it seeks to raise family income, can be seen as a means of helping the very poor into the cash economy, which is always, in a sometimes remote but still relevant sense, connected to global markets.

If the picture of microcredit is as an "extension" of the global market, a ladder by which to assist people "up" into the fully commercial economy that is ultimately what the global market is about, microcredit cannot be conceived as a permanent subsidy. A permanent subsidy, as we shall shortly see, suggests a different relationship between microcredit and economic globalization. Microcredit acts as an extension of the global economy only if it assists the poor, graduates them, ${ }^{84}$ into the real market economy, and then moves on. If it is permanent, or at least permanently required in a subsidized fashion, then it connotes a very different

83. To be sure, microcredit is simply one of the many development mechanisms that might touch the lives of the poor that could be thought in this way. We are here focused on microcredit as exemplary and not as exclusive.

84. For an introduction to the issue, see Katherine STEARNS, Programa DE DESAROllo DE MICROEMPRESAS: ES UN MITO LA GRADACION DEL CLIENTE? (1990) (ACCION Internacional Serie de Documentes de Discusion No. 3). 
relationship. ${ }^{85}$ What, then, is the relationship of microcredit to economic globalization if we think the second possibility is the correct one: the possibility that some part of the world's population, whether the current $20 \%$ figure that is often cited or some other, will never be efficiently drawn into the system of global markets, even with microcredit? What if, for whatever reasons, whatever skills the poor acquire will not be enough to draw them into the advantages of the global market? Or, put another way, what is the idea behind microcredit if microcredit borrowers - not a pool of borrowers that evolves and changes as some do well and graduate into "real" economy and are replaced by new entrants, but instead the same borrowers - are never able to get beyond the need for subsidy? What if their enterprises never achieve profitability or revenues sufficient to eliminate the need for subsidy - even though the subsidy to some extent leverages family income by increasing volume, for example, in a family microbusiness? How should microcredit conceive of itself?

In one sense, microcredit still completes the universalist moral obligation of global capitalism. After all, it still brings markets to very poor people who are left out of the system of global markets. But it does so in a very different way and in a very different sense. The picture is no longer one of being a mechanism, a bridge, a ladder, by which capitalism is extended downwards to draw people in. The picture, by contrast, is one in which microcredit creates, instead, faux markets out of subsidized funds, markets that are artificially created and sustained precisely because the "real" global market will never draw these very poor people upwards and into it. The need for faux markets is created on account of market failure by the "real" market.

In describing markets created or sustained by microcredit institutions as "faux" markets, I do not intend to denigrate them. There can be sound social policy reasons why it is useful to create such markets even when the ultimate function is not to draw people into the "real" market. Even within an artificially subsidized market, for example, it may be useful, effective policy to introduce market discipline in the allocation of credit and capital and to require its turnover through payment, even if the capital deployed is ultimately subsidized. The mechanisms of the market, even in subsidized institutions, may provide for greater efficiencies than more bureaucratic mechanisms of welfare distribution. The market may provide a useful way of imparting skills in such matters as money and budgeting; it may be a means of empowering women within their villages or households. ${ }^{86}$ These may be convincing reasons why the use of a

85. I emphasize permanently needed subsidy because, as noted above, in actual practice, microcredit programs are typically eager to hang on to their best borrowers, those who have successfully repaid earlier loans, because they pose both fewer risks and lower monitoring costs for the same interest rate and, for the same reasons, can perhaps take on larger loans, thus creating volume per borrower and, ideally, helping to overcome the endemic problem of economies of scale in borrowing. But these are all ways of reducing the subsidy applied per borrower, and so the point is the same.

86. This is the view taken by the Microcredit Summit Declaration in justifying microcredit. The Declaration sees microcredit's role as far wider than simply providing a means "up" into 
subsidized market is preferable to other allocation mechanisms and why microcredit should operate as it typically does. But it is not the same rationale as extending the global market to the very poor. The rationale, rather, is that even in circumstances where microcredit-fostered markets do not ultimately connect with global markets (except in indirect senses of currency and money in the abstract), and where ultimately microcredit clients are not able to graduate out of (often highly) subsidized credit programs, a faux market is better than no market at all. The point is not simply that some subsidy to the very poor is better than none at all, but that a subsidy to the poor organized through a market mechanism, even an artificially supported one, is better than a non-market one, at least in such matters as provision of credit and capital. Other kinds of social goods, such as education and health care, present very different issues, for which markets might be thought inapposite, but in such matters as credit, market mechanisms, even if artificial, are the most efficient means of distribution.

\section{Microcredit's Ambivalence About Global Markets and Their Universalist Moral Justification}

The difference between the two ways of viewing microcredit described above - as an extension of, or as an alternative to, the global economy - has a very significant practical consequence for how microcredit programs are evaluated for effectiveness, whether by donors, microfinance institutions themselves, or others. If, as discussed earlier, microfinance institutions are themselves fundamentally about bringing clients upwards into the "real" market, then the test of success is precisely how many clients are able to graduate to unsubsidized credit; this figure may be taken as a reasonable proxy for increases in family income and other poverty relief indicators. This does not mean, to be sure, that a microfinance provider could not conceive of its mission as creating a base of stable, unsubsidized borrowers who over time finance operations of the microfinance institution and create sustainability. But a provider could instead decide to steer successful clients toward commercial institutions, and so never reap the benefits of the investment in human capital as measured by the self-sustainability of the microfinance institution.

If, by contrast, microfinance is conceived in terms of remedying market failure and of creating permanently subsidized markets and permanently

\footnotetext{
the "real" market:

Microcredit can play an important role in increasing access to basic social services and thereby enhancing the well-being of very poor people. A poor woman who is able to access microcredit can also gain increased access to primary health care, safe water and sanitation for her family, and family planning information and services... [R]egular meetings [of lending circles] provide an excellent forum for learning and discussion about health care and sanitation, family planning, ending marriage dowries and running business, among other things.

MICROCREDIT SUMMTT DECLARATION, supra note 21, at 14.
} 
subsidized clients, then its success must be measured not by graduation rates but instead by broader measures of welfare improvements among the very poor and increases in their human capital generally, including education, health, nutrition and so on. This is a much broader measure of success and, while surely important, is much less susceptible to quantification and measurement in the venture capital sense of return on social investment. Moreover, as a criterion of success for microfinance institutions, it simply establishes microfinance as one of several conduits for the provision of welfare for the poor.

Stripped of its special bootstrapping element, given that the model does not presuppose graduation "up" into the real market, microcredit must compete with other, often direct forms of welfare provision for the very poor, including direct investment in health care, education, and the rest of direct social services for the poor. Microcredit is special among these only insofar as it promises a model that accumulates and reproduces capital among the poor. If it is simply a vehicle for increasing access to other social services, then resources could instead be put toward simply providing more of those services, and providing them more directly. It would not be unfair to say that not infrequently, microfinance institutions have sought to justify themselves on grounds that swing back and forth between these two fundamentally different rationales. When pressed for why microfinance should get additional resources, organizations argue that microfinance is special because it accumulates and reproduces capital within poor communities. When pressed for why continuing subsidies are needed, not just for the microfinance institutions that never seem to become self-sustaining but also for the continuing faux market of borrowers, they argue that even if microcredit does not accumulate and reproduce finance capital within poor communities, it serves as an organizing mechanism for access to other welfare services by increasing the human capital necessary for the poor to get hold of those basic resources. These are fundamentally different rationales for microcredit, and they imply fundamentally different measures of effectiveness.

But beyond these practicalities, the difference between these two rationales also signals a key difference in attitude toward economic globalization. It signals the presence of a deep and persistent ambivalence toward global markets on the part of microcredit because, of course, microcredit programs often sense that, to some extent, both of these conceptions are true and desirable. Experiencing both the sense of fulfilling the promise of the market and the sense of remedying the market's failure-each of which is a feeling deeply embedded in the experience of microcredit - is a recipe for deep ambivalence about the global market.

\section{CONCLUSION: SHARING OUT THE LOAVES AND FISHES}

The conclusion is a modest one. This Article has sought to do no more than provide one account of the persistent ambivalence that microcredit, as a widespread development paradigm and global practice, conveys about 
both itself as a social practice and about another large-scale social practice: economic globalization. Microcredit organizations and their practitioners cannot help but have views of one kind or another about the spread of global capitalism. Global capitalism makes, as we have seen, strong promises about its effects on the world's poor who are the quotidian constituency of microcredit programs. Microcredit cannot help but bump up, ideologically speaking, against claims of global markets about what is most effective for helping the world's poor. Moreover, because microcredit puts market strategies at the core of its paradigm, its self-conception and its conceptual relationship to global markets are inevitably at issue, especially as global markets spread.

This Article has suggested, however, that the truest description of the microcredit's self-conception of global capitalism is an uneasy ambivalence. This is because in one circumstance or another, microcredit can be seen either as handmaid to global markets, a subsidized helping hand aimed at drawing poor people into global markets, or as a mechanism for dealing with the market's failure to make good its promise to include everyone. The Article has attempted to give a sense of the ways in which microcredit as a practice embraces and utilizes market principles. Since microcredit organizations are frequently NGOs, however, operating outside regular credit market constraints but within the constraints of what might be termed the "nonprofit capital market" (i.e., fundraising demands), market principles are sometimes either hard to apply or simply inapposite. This is particularly true when it comes to the measurement of outcomes; the ordinary measure of a for-profit business, profitability and therefore self-sustainability, is not necessarily a sure-fire indicator of a microcredit program's success or failure. It is necessary to look further to how the program conceives of its relation to the "real" market and its clients. Moreover, this Article has not sought to serve as an introduction to microcredit; indeed, one of the most important questions, "Does microcredit actually work?" has not been addressed at all.

The Article has sought to distill a certain set of moral claims about economic globalization out of the writings and speeches of a few exemplary figures. The essence of those claims has been that economic globalization ought to be judged in considerable part by whether it improves the life chances of the very poor. Kofi Annan has urged that what the world's poor need is more globalization, not less, and that the very poor need to be made part of globalization; he apparently regards the global market as in need of transnational regulation if it is to include everyone. The fundamental claim that Annan makes, however, is that global capitalism should be regarded as universal in the sense that it has a moral obligation to include everyone. Microcredit, the Article has suggested, can be seen either as a means to include everyone, an extension of the market, or else as the subsidizer of faux markets to provide a remedy for failure by the real markets.

What remains to be asked is whether the rest of us, the world's comfortable and educated bourgeoisie, can learn anything from this 
admittedly abstract consideration of the differing conceptions of microcredit and globalization that helps us understand our own ambivalence toward economic globalization. The Article suggested at the beginning that our ambivalence with respect to economic globalization is that we both desire it and fear it both for ourselves and for others. It seems to me that what this consideration of microcredit and globalization can do for us is tell that our ambivalence is based on something real, the very real possibility that, left to its own devices, economic globalization could easily leave whole swaths of the world's population untouched by its benefits. If we are committed to the moral universalism of global markets, if we are committed to accepting global markets as a universal system, then it seems incumbent upon us to accept and fulfill the moral obligation of universalism. Whether the logic of the global market will accept the challenge of its own morality is an open question.

I end this Article on a note of ambivalence with a poem by David Whyte. ${ }^{87}$

Loaves and Fishes

This is not

the age of information.

This is not

the age of information.

Forget the news,

and the radio,

and the blurred screen.

This is the time

of loaves

and fishes.

People are hungry,

and one good word is bread

for a thousand.

87. David Whyte, The House of Belonging, in RUGMAN, supra note 71 , at 88 . 